\title{
UJI KANDUNGAN KHLORIDA PADA AIR MINUM DALAM KEMASAN (AMDK) PRODUKSI PANTAI BARAT SELATAN ACEH
}

\author{
Zaulfikar Abbas ${ }^{1)}$, Muhamad Reza ${ }^{2)}$ \\ ${ }^{1)}$ Fakultas Teknik Universitas Teuku Umar Meulaboh \\ ${ }^{2)}$ Fakultas Kesehatan Masyarakat Universitas Teuku Umar Meulaboh
}

\begin{abstract}
The content of chloride in drinking water, including the Bottled Drinking Water (bottled water) must correspond Ministry of Health of the Republic of Indonesia number 492/Menkes/PER/ IV/2010, which should not exceed $250 \mathrm{mg} / \mathrm{l}$. Excess chloride load in the body are harmful to health. Therefore, the testing of any content of chloride in drinking water should always be done properly and responsibly.

Based on the Decree No. 492 of 2010, researchers wanted to determine the content of chloride from 7 (seven) brands of Bottled Drinking Water (bottled water) local production region south west coast of Aceh province. The results of the study illustrate that the chloride load on Bottled Drinking Water (bottled water) that exceed $250 \mathrm{mg} / \mathrm{l}$ or not, so that eventually we can conclude the seven brands of Bottled Drinking Water (bottled water) is feasible or not feasible consumed by the public.

To execute this research, researchers using the descriptive method is based on laboratory test results. The sampling technique is purposive sampling, where each brand is taken three (3) samples of drinking water in glass packaging 220-230 ml from markets / locations. The results of observations, researchers found seven brands of Bottled Drinking Water (bottled water). Tests conducted repetition 2 times. So the total number is 42 samples tested.

The results showed that from 42 samples against the chloride load test results may vary from 11.3032 to $25.4322 \mathrm{mg} / \mathrm{l}$. The content is still very low compared with drinking water quality standard specified in Permenkes 492 in 2010, which does not exceed $250 \mathrm{mg} / \mathrm{l}$. From the results obtained it can be concluded that the seven brands of Bottled Drinking Water (bottled water) production region of the South West Coast of Aceh is safe for public consumption because the content is still very low khlordanya from quality standards established Ministry of Health of the Republic of Indonesia.
\end{abstract}

Keywords: chloride, bottled water

\section{PENDAHULUAN}

Ketersediaan air adalah sangat penting bagi kelangsungan hidup manusia, maka penyediaan air baik dari segi kualitas maupun kuantitas mutlak diupayakan ditengah-tengah kehidupan manusia baik secara individu maupun kelompok. Dari kualitasnya, air minum harus dapat memenuhi kriteria atau standar air minum. Kualitas air minum harus diperhatikan sebelum dikonsumsi, sebab air yang tidak bersih dapat mengganggu kesehatan manusia. 
Oleh karena itu, air minum yang digunakan harus memenuhi persyaratan air minum sebagaimana disyaratkan dalam Permenkes Nomor 492 Tahun 2010 Tentang Persyaratan Kualitas Air Minum, yaitu : memenuhi syarat fisik, kimia dan biologi. Demikian juga untuk Air Minum Dalam Kemasan (AMDK) sebagaimana diproduksi lokal di wilayah pantai barat selatan propinsi Aceh.

Menurut peraturan Direktur Jendral Industri Agro dan Kimia Nomor 29/IAK/per/3/2007 tentang pedoman pengawasan Air Minum Dalam Kemasan (AMDK) di pabrik, dimana Air Minum Dalam Kemasan (AMDK) adalah air baku yang telah diproses, dikemas, dan aman diminum. Air Minum Dalam Kemasan (AMDK) merupakan salah satu produk industri yang SNI-nya telah diberlakukan secara wajib, oleh karena itu pengawasan terhadap perusahaan Air Minum Dalam Kemasan (AMDK) adalah mutlak harus dilakukan

Dalam proses pengolahan air minum, demikian juga Air Minum Dalam Kemasan (AMDK) juga mengunakan desinfektan untuk membunuh bakteri-bakteri dan mikroorganisme yang terdapat dalam air tersebut. Desinfektan yang sering digunakan adalah gas khlorin. Hal ini karena biayanya yang relatif lebih murah, mudah, dan efektif. Kelebihan khlorin dalam air dapat diuji berdasarkan kandungan khlorida yang terdapat dalam air tersebut.

Soemirat (2011), mengatakan khlorida adalah senyawa halogen khlor (Cl). Toksisitasnya tergantung pada gugus senyawanya. Misalnya $\mathrm{NaCl}$ sangat tidak beracun, tetapi karbosil khlorida sangat beracun.

Khlorin di dalam air akan berubah menjadi asam klorida. Zat ini kemudian di netralisasi oleh sifat basa dari air sehingga akan terurai menjadi ion hidrogen dan ion hipoklorit. Perhatikan reaksi kimia berikut.

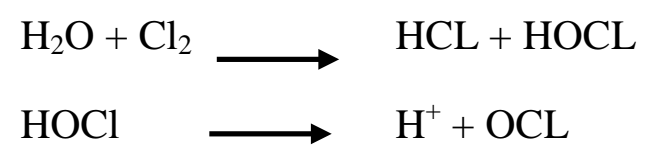

Khlorin sebagai desinfektan terutama bekerja dalam bentuk asam hipoklorit (HOCl) dan sebagian kecil dalam bentuk ion hipoklorit (OCl). Khlorin dapat bekerja dengan efektif sebagai desinfektan jika berada dalam air dengan pH sekitar 7. Jika Nilai pH air lebih dari 8,5 maka 90\% 
dari asam hipoklorit itu akan mengalami ionisasi menjadi ion hipoklorit. Dengan demikian, kemampuan desinfektan yang dimiliki khlorin menjadi lemah atau berkurang (Sumantri.2010).

\section{METODE PENELITIAN}

Metode penelitian ini menggunakan metode deskriptif berdasarkan hasil uji laboratorium. Metode ini dilakukan dengan melihat gambaran dari analisis kandungan khlorda pada Air Minum Dalam Kemasan (AMDK) beberapa produksi lokal pantai barat dan selatan propinsi Aceh.

Hasil observasi, peneliti mendapati 7 (tujuh) merek Air Minum Dalam Kemasan (AMDK) yang diproduksi dalam kabupaten sepanjang pantai barat dan selatan propinsi Aceh. Oleh karena itu ketujuh merek Air Minum Dalam Kemasan (AMDK) merupakan populasi penelitian. Adapun teknik pengambilan sampel dilakukan secara purposive sampling, dimana setiap merek diambil 3 (tiga) sampel air minum dalam kemasan gelas 220-230 ml dari pasar atau tempat yang berbeda. Jadi, keseluruhan berjumlah 21 sampel dan setiap sampel diuji 2 (dua) kali, sehingga jumlah keseluruhan pengujian sebanyak 42 sampel uji.

Dalam setiap sampel uji tidak ditunjukkan merek Air Minum Dalam Kemasan (AMDK) yang sedang diuji. Setiap merek diberi kode A, B, C, D, E, F dan G. Kemudian kode abjad tersebut ditambah notasi 1, 2 dan 3 yang menunjukkan tempat kesatu, tempat kedua dan tempat ketiga merek Air Minum Dalam Kemasan (AMDK) tersebut diperoleh. Selanjutnya ditambah kode R1 dan R2 yang menunjukkan pengulangan (replika) pengujian sampel uji.

\section{PENGUJIAN KANDUNGAN KHLORIDA}

Uji kandungan khlorida menggunakan metode spektrofotometri. Bila N-dietil-pfenilendiamin (DPD) sebagai indikator dibubuhkan pada suatu larutan yang mengandung khlorida akan membentuk warna merah. Warna yang terjadi dibaca spektrofotometer pada panjang gelombang $515 \mathrm{~nm}$.

\section{HASIL DAN PEMBAHASAN}

Hasil uji kandungan khlorida dari 42 sample uji disajikan dalam tabel 1 . Tabel 1 menunjukkan bahwa kandungan khlorida dari ketujuh merek Air Minum Dalam Kemasan 
(AMDK) yang dilabel sebagai A, B, C, D, E, F dan G bervariasi berkisar 11,3032 - 25,4322 mg/l, namun kandungan khlorida tersebut masih sangat rendah dari kandungan khlorida yang diizinkan sesuai Permenkes Nomor 492 Tahun 2010, yaitu tidak melebihi 250 mg/l.

Penelitian kandungan khlorida juga telah dilakukan terhadap tiga depot air minum isi ulang diseputaran kampus Universitas Syiah Kuala dan tiga depot air minum isi ulang di kawasan Mata Ie Banda Aceh. Dari keenam depot air ulang tersebut diperoleh kandungan khlorida juga sangat rendah dari yang diizinkan pemerintah, yaitu berkisar antara 9,53 mg/l - 10,71 mg/l (Martupa, 2014).

Nurhayati R (2015), melaporkan kandungan khlorin bebas yang terdapat pada beberapa air minum, baik air minum yang berasal dari PDAM, air sumur gali, air minum, air minum isi ulang dan air minum dalam kemasan. Hasil penelitian menunjukkan kadar khlorin yang bervariasi antara 0,2 - 1,45 mg/l. Hasil ini juga lebih rendah dari permenkes nomor 492 tahun 2010, dimana kadar khlorin tidak boleh melebihi 5 mg/l.

Kandungan khlorin dan khlorida berhubungan erat dengan keberadaan bakteri/ mikroorganisme dalam air, demikian juga dalam air minum. Dimana kandungan khlorin minimum 0,2 mg/l dapat menghilangkan bakteri e-coli dalam air (Azhar, 2012). Hal ini juga selaras dengan laporan peneliti sebelumnya tentang kandungan bakteri e-coli pada ketujuh Air Minum Dalam Kemasan (AMDK) yang sama dalam penelitian ini, dimana kandungan bakteri ecoli dalam ketujuh sampel Air Minum Dalam Kemasan (AMDK) tersebut adalah 0 mg/l sesuai permenkes 492 tahun 2010 (Zaulfikar, 2015).

Jadi, baik kandungan khlorin maupun kandungan khlorida dalam air minum adalah mutlak diperlukan untuk menjamin ketiadaan bakteri, terutama bakteri e-coli. Akan tetapi baik kandungan khlorin maupun kandungan khlorida tersebut harus sesuai Permenkes Republik Indonesia Nomor 492 Tahun 2010 Tentang Persyaratan Air Minum, yaitu tidak boleh melebihi 5 mg/l untuk kandungan khlorin dan tidak boleh melebihi 250 mg/l untuk kandungan khlorida.

Dari pemaparan diatas membuktikan bahwa kualitas Air Minum Dalam Kemasan (AMDK) produksi pantai barat dan selatan Aceh adalah sangat baik dan memenuhi syarat kesehatan serta aman dikonsumsi masyarakat, karena tidak akan menimbulkan dampak dari kandungan khloridanya. 
Tabel 1 : Hasil Uji Kandungan Khlorida dari 7 Merek Air Minum Dalam Kemasan (AMDK)

\begin{tabular}{|c|c|c|c|}
\hline \multirow{2}{*}{ No. } & \multirow{2}{*}{$\begin{array}{c}\text { Sampel } \\
\text { ID }\end{array}$} & \multicolumn{2}{|c|}{ Hasil Analisa } \\
\hline & & Replika & $\begin{array}{c}\mathrm{Cl} \\
\mathrm{mg} / \mathrm{l}\end{array}$ \\
\hline 1. & \multirow{2}{*}{ A 1} & $\mathrm{R}-1$ & 19,7806 \\
\hline 2. & & $\mathrm{R}-2$ & 14,1290 \\
\hline 3. & \multirow{2}{*}{ A 2} & $\mathrm{R}-1$ & 14,1290 \\
\hline 4. & & $\mathrm{R}-2$ & 14,1290 \\
\hline 5. & \multirow{2}{*}{ A 3} & $\mathrm{R}-1$ & 16,9548 \\
\hline 6. & & $\mathrm{R}-2$ & 19,7806 \\
\hline 7. & \multirow{2}{*}{ B 1} & $\mathrm{R}-1$ & 16,9548 \\
\hline 8. & & $\mathrm{R}-2$ & 16,9548 \\
\hline 9. & \multirow{2}{*}{ B 2} & $\mathrm{R}-1$ & 19,7806 \\
\hline 10. & & $\mathrm{R}-2$ & 22,6064 \\
\hline 11. & \multirow{2}{*}{ B 3} & $\mathrm{R}-1$ & 22,6064 \\
\hline 12. & & $\mathrm{R}-2$ & 25,4322 \\
\hline 13. & \multirow{2}{*}{ C 1} & $\mathrm{R}-1$ & 22,6064 \\
\hline 14. & & $\mathrm{R}-2$ & 19,7806 \\
\hline 15. & \multirow{2}{*}{ C 2} & $\mathrm{R}-1$ & 16,9548 \\
\hline 16. & & $\mathrm{R}-2$ & 19,7806 \\
\hline 17. & \multirow{2}{*}{ C 3} & $\mathrm{R}-1$ & 22,6064 \\
\hline 18. & & $\mathrm{R}-2$ & 25,4322 \\
\hline 19. & \multirow{2}{*}{ D 1} & $\mathrm{R}-1$ & 19,7806 \\
\hline 20. & & $\mathrm{R}-2$ & 19,7806 \\
\hline 21. & \multirow{2}{*}{ D 2} & R-1 & 14,1290 \\
\hline 22. & & $\mathrm{R}-2$ & 14,1290 \\
\hline 23. & \multirow{2}{*}{ D 3} & $\mathrm{R}-1$ & 11,3032 \\
\hline 24. & & $\mathrm{R}-2$ & 14,1290 \\
\hline
\end{tabular}

\begin{tabular}{|c|c|c|c|}
\hline \multirow{2}{*}{ No. } & \multirow{2}{*}{$\begin{array}{c}\text { Sampel } \\
\text { ID }\end{array}$} & \multicolumn{2}{|c|}{ Hasil Analisa } \\
\hline & & Replika & $\begin{array}{c}\mathrm{Cl} \\
\mathrm{mg} / \mathrm{l}\end{array}$ \\
\hline 25. & \multirow{2}{*}{ E 1} & $\mathrm{R}-1$ & 14,1290 \\
\hline 26. & & $\mathrm{R}-2$ & 19,7806 \\
\hline 27. & \multirow{2}{*}{ E 2} & $\mathrm{R}-1$ & 19,7806 \\
\hline 28. & & $\mathrm{R}-2$ & 22,6064 \\
\hline 29. & \multirow{2}{*}{ E 3} & $\mathrm{R}-1$ & 22,6064 \\
\hline 30. & & $\mathrm{R}-2$ & 22,6064 \\
\hline 31. & \multirow{2}{*}{ F 1} & $\mathrm{R}-1$ & 16,9548 \\
\hline 32. & & $\mathrm{R}-2$ & 16,9548 \\
\hline 33. & \multirow{2}{*}{ F 2} & $\mathrm{R}-1$ & 16,9548 \\
\hline 34. & & $\mathrm{R}-2$ & 14,1290 \\
\hline 35. & \multirow{2}{*}{ F 3} & $\mathrm{R}-1$ & 14,1290 \\
\hline 36. & & $\mathrm{R}-2$ & 16,9548 \\
\hline 37. & \multirow{2}{*}{ G 1} & $\mathrm{R}-1$ & 14,1290 \\
\hline 38. & & $\mathrm{R}-2$ & 14,1290 \\
\hline 39. & \multirow{2}{*}{ G 2} & R-1 & 16,9548 \\
\hline 40. & & $\mathrm{R}-2$ & 14,1290 \\
\hline 41. & \multirow{2}{*}{ G 3} & $\mathrm{R}-1$ & 16,9548 \\
\hline 42. & & $\mathrm{R}-2$ & 11,3032 \\
\hline
\end{tabular}

\section{KESIMPULAN}


Hasil penelitian menunjukkan bahwa dari 42 sampel uji memberikan hasil kandungan khlorida dalam ketujuh merek Air Minum Dalam Kemasan (AMDK) produksi pantai barat dan selatan propinsi Aceh adalah bervariasi yang berkisar 11,3032 - 25,4322 mg/l, namun juga masih sangat rendah dari kandungan khlorida yang diizinkan sesuai Permenkes Nomor 492 Tahun 2010, yaitu tidak melebihi $250 \mathrm{mg} / \mathrm{l}$.

Jadi, dari hasil yang diperoleh tersebut dapat disimpulkan bahwa ke tujuh merek Air Minum Dalam Kemasan (AMDK) produksi wilayah Pantai Barat Selatan Aceh adalah aman dikonsumsi masyarakat, karena tidak menimbulkan dampak dari kandungan khlorida.

\section{SARAN}

Dalam rangka menyongsong dan menghadapi era kesepakatan Masyarakat Ekonomi Asean 2015, maka pemerintah melalui Dinas Kesehatan Kabupaten dan Balai Pengawasan Obat dan Makanan (BPOM) harus serius dan terus menerus melakukan pengawasan dan pembinaan terhadap kualitas makanan dan minuman olahan masyarakat agar mampu bersaing dengan produk sejenis lainnya yang berasal dari daerah lain atau dari masyarakat negara-negara ASEAN lainnya.

\section{DAFTAR PUSTAKA}

Azahar, 2012, Pengaruh Residual Khlorin Terhadap Kualitas Mikrobiologi Pada Jaringan Pipa Distribusi Air Bersih (Studi Kasus: Jaringan Distribusi Air Bersih IPA Cilandak), Skripsi, Program Studi Teknik Lingkungan, Fakultas Teknik, Universitas Indonesia.

Lubis, M., dan Zulfadli, 2014. Analisis Kandungan Klorida dalam Air Minum Isi Ulang di Seputaran Kampus Unsyiah dan Mata Ie Secara Argentometri Mohr, http://martupalubisgabriel.blogspot.co.id/: diposting pada 14 Januari 2014.

Menteri Kesehatan Republik Indonesia, 2010, Peraturan Menteri Kesehatan Republik Indonesia Nomor 492/Menkes/IV/2010 Tentang Persyaratan Air Minum, Jakarta: Kementerian Kesehatan Republik Indonesia.

Notoatmodjo. S., 2010, Metodologi Penelitian Kesehatan, Jakarta: Rineka Cipta. 
Nurhayati R.,, Diah N., dan Witi K., 2015, Pengaruh Jenis Air Yang Digunakan Terhadap Kadar Klorin Pada Air Seduhan Kertas Pembungkus Teh Celup, http://jurnal.poltekkespalembang.ac.id/

Peraturan Direktur Jenderal Industri Agro dan Kimia Nomor 2/lak/Per/3/2007 Tentang Pedoman Pengawasan Penerapan SNI Air Minum Dalam Kemasan Di Pabrik. 2007 Jakarta: Dirjen Industri Agro dan Kimia.

Soemirat, J. 2011. Kesehatan Lingkungan. Yogyakarta: Gajah Mada University Press

Sumantri. A. 2010. Kesehatan lingkungan. Jakarta: Kencana Prenada Media Grup.

Zaulfikar, A., dan Wintah, 2015, Uji Kandungan Bakteri E-Coli Pada Air Minum Dalam Kemasan Beberapa Produk Lokal Pantai Barat Selatan Aceh, Universitas Teuku Umar, Jurnal Optimalisasi, Volume 1 (1). 